\title{
Factors responsible for subclinical mastitis in cows caused by Staphylococcus chromogenes and its susceptibility to antibiotics based on bap, fnbA, eno, mecA, tetK, and ermA genes
}

\author{
M. Bochniarz, ${ }^{* 1}$ Ł. Adaszek,† B. Dzięgiel,† A. Nowaczek,‡ W. Wawron, ${ }^{*}$ R. Dąbrowski, ${ }^{*}$ M. Szczubiał, ${ }^{*}$ \\ and S. Winiarczyk† \\ *Department and Clinic of Animal Reproduction, Faculty of Veterinary Medicine, \\ †Department of Epizootiology and Clinic of Infectious Diseases, Faculty of Veterinary Medicine, and \\ †Institute of Biological Bases of Animal Diseases Sub-Department of Veterinary Prevention and Avian Diseases, University of Life Sciences, \\ Lublin 20-612, Poland
}

\section{ABSTRACT}

The aim of this study was to recognize selected factors of virulence determining the adhesion of Staphylococcus chromogenes to cows' udder tissues in subclinical mastitis and to evaluate the susceptibility of this pathogen to antibiotics. The subjects of the study were 38 isolates of Staph. chromogenes from 335 samples of milk from cows with subclinical coagulase-negative staphylococci mastitis. Somatic cell count ranged between 216,000 and $568,000 / \mathrm{mL}$ of milk (average $356,000 / \mathrm{mL}$ of milk). We confirmed the ability to produce slime in 24 isolates $(63.2 \%)$, and the ability to produce protease in 29 isolates $(76.3 \%)$. In each slime-producing isolate, the bap gene was not found, and the $f n b A$ and eno genes were not detected. In vitro tests showed that ceftiofur had the highest effectiveness against Staph. chromogenes (89.5\% of susceptible isolates). Minimum inhibitory concentrations ranged from 0.06 to $2 \mu \mathrm{g} / \mathrm{mL}$ for susceptible isolates. The minimum concentrations required to inhibit growth of 90 and $50 \%$ of the isolates for ceftiofur were at or below the cutoffs recommended by the Clinical and Laboratory Standards Institute $(2$ and $0.06 \mu \mathrm{g} /$ $\mathrm{mL}$, respectively). A significant percentage of the isolates were susceptible to other $\beta$-lactam antibiotics: amoxicillin with clavulanic acid $(84.2 \%)$ and ampicillin (81.6\%). The lowest effectiveness among $\beta$-lactams was for penicillin ( $73.7 \%$ of susceptible isolates), and the minimum inhibitory concentration for penicillin ranged from $<0.06$ to $8 \mu \mathrm{g} / \mathrm{mL}$. None of the examined isolates had the mecA gene, but $\beta$-lactamase was detected in 4 isolates (10.5\%). Erythromycin and oxytetracycline exhibited the lowest activity against Staph. chromogenes

Received July 9, 2016.

Accepted August 18, 2016.

${ }^{1}$ Corresponding author: mariolabochniarz@interia.pl
(71.1 and $63.2 \%$ of susceptible isolates, respectively). The genes tetK (6 isolates) and ermA (1 isolate) were also detected.

Key words: Staphylococcus chromogenes, coagulasenegative staphylococci, subclinical mastitis

\section{INTRODUCTION}

Mastitis is one of the most common diseases in dairy cows, and its occurrence is connected with substantial economic losses (Pyörälä and Taponen, 2009; Frey et al., 2013; Tremblay et al., 2013; Tomazi et al., 2015). Each type of mastitis results in decreases in milk production and quality. The milk becomes unsuitable for human consumption and for technological processes. Bacterial mastitis is caused by several pathogens, but the most frequently isolated bacterial species are CNS (Pyörälä and Taponen, 2009).

Widely found in the natural environment, CNS colonize both animal and human skin and mucous membranes. For many years, CNS were thought to be nonpathogenic, but they have now become known as the predominant etiological factor in mastitis in cows in numerous countries (Makovec and Ruegg, 2003; Pitkälä et al., 2004; Rajala-Schultz et al., 2004, Taponen et al., 2007). More than 15 strains of CNS are known and have been identified as etiological factors in mastitis (Thorberg et al., 2009; Waller et al., 2011; Tomazi et al., 2015). Based on the literature (Tomazi et al., 2015) and one of our previous studies (Bochniarz et al., 2013), we can infer that Staph. chromogenes is one of the most common CNS species in mastitis. It is interesting to explore what mechanisms enable this pathogen, which appears in saprophytic form in the environment, to overcome the physical barrier of the teat canal, adhere to cells, and form biofilm, which protects it against removal from the udder during milking.

The initial stages of infection involve Staphylococcus spp. proteins that are responsible for adherence to the 
host extracellular matrix (described as microbial surface components recognizing adhesive matrix molecules, MSCRAMM) and other surface proteins that promote biofilm formation or resistance to opsonophagocytosis (Cree et al., 1994). Staphylococcus spp. proteins have the ability to bind to the components of extracellular matrix-laminin and fibronectin, among others (Paulsson et al., 1992). Laminin is a component of the foundation membrane between the epithelial cells and connective tissue in the mammary gland. Fibronectin appears in 2 forms: soluble plasma fibronectin, which occurs in various bodily fluids, and insoluble cellular fibronectin, which is combined with the cells of different tissues. Owing to the biological functions of fibronectin (facilitation of phagocytosis, contributions to the reconstruction of damaged tissues, regulation of cytoskeleton organization), it becomes a target molecule for the bacteria. Fibronectin-binding protein is encoded by the $f n b A$ gene, and laminin-binding protein is encoded by the eno gene (Simojoki et al., 2012).

Invasiveness of pathogens is also determined by their ability to proliferate on the surface where they adhere (Melchior et al., 2011). During this process, bacterial biofilm is formed out of the cellular matrix and daughter cells adherent to it, bound together by slime produced by the bacteria. This substance is described as amorphous and sticky, loosely attached to the cell wall of microorganisms (Matthews et al., 1991). The polysaccharide molecule (molecule weight 100,000 kDa) is a main component of slime. It is largely made up of glucose and $N$-acetyl-glucosamines, and it is resistant to enzymes produced by the host organism. Biofilm forms a protective barrier against phagocytosis, inhibits opsonization by the antibodies, and hinders the access of antibiotics (Costerton et al., 1999; Melchior et al., 2006). Biofilm formation plays an important role in virulence, but its role as a virulence factor in Staph. chromogenes has been poorly studied (Tremblay et al., 2013).

Staphylococcus survival in the udder depends on the availability of iron in its free form, $\mathrm{Fe}^{3+}$. In the inflammatory process, a significant increase in levels of ironbinding proteins (lactoferrin and transferrin) in milk can be observed. These substances hinder the availability of iron to bacteria (Chaneton et al., 2008). The ability to produce protease, which allows the pathogens to access the iron that is vital to their survival, is one of the most essential elements of their pathogenicity.

The aim of this study was to identify the factors that determined the adhesion and survival of Staph. chromogenes isolates in the udders of cows with subclinical mastitis, and to evaluate the isolates' susceptibility to antibiotics.

\section{MATERIALS AND METHODS}

The subject of the study were 38 isolates of Staph. chromogenes taken from 335 samples of milk from cows with subclinical mastitis caused by CNS. These isolates originated from the milk of 27 cows from farms in the Lubelskie region of Poland. In 16 cows, Staph. chromogenes was isolated from only 1 quarter, and in 11 cows it was isolated from 2 quarters. Cows with Staph. chromogenes were from 5 herds that used various housing systems (4 freestall or loose and 14 tiestall systems). Clinical examination of cows and macroscopic evaluation of the milk were performed before milk samples were collected for bacteriological testing. Cows received no medications during the ongoing lactation.

Milk was bacteriologically tested according to generally accepted procedures. Milk samples were brought to room temperature and then thoroughly mixed and cultured on agar medium (BTL, Łódź, Poland) supplemented with sterile, defibrinated sheep blood (5\% of the agar solution volume). After incubation for $24 \mathrm{~h}$ at $37^{\circ} \mathrm{C}$ in aerobic conditions, pathogens were initially identified based on colony morphology and gramstained using microscopic specimens.

Identification of CNS species was performed using a commercial API Staph test (bioMerieux, Marcyl'Étoile, France) based on determinations of 19 biochemical features. The procedure followed the manufacturer's recommendations (http://biomerieux-usa.com/ clinical/api).

Mastitis classification was conducted according to generally accepted rules (Gentilini et al., 2002; De Vliegher et al., 2003; Moon et al., 2007), which include clinical examination of the cows, milk bacteriological testing, and SCC in milk samples (Fossomatic; Foss, Hillerød, Denmark). An SCC $>200,000 / \mathrm{mL}$ of milk and the presence of bacteria in milk (despite a lack of general symptoms in the cow) was considered to be subclinical mastitis.

\section{Evaluation of Capacity to Form Slime}

Slime-producing capacity was determined using Congo red agar (Sigma, St. Louis, MO; Freeman et al., 1989). Overnight cultures in TSB (tryptic soy broth) were inoculated onto Congo red agar plates and incubated at $37^{\circ} \mathrm{C}$ for $24 \mathrm{~h}$. Biofilm formation was detected based on the presence of black or almost black colonies on the agar.

\section{Evaluation of Capacity to Form Protease}

A base solution of nutrient gelatin (Oxoid, Basingstoke, UK) with $128 \mathrm{~g}$ concentration in $1 \mathrm{~L}$ of distilled 
water was sterilized at $121^{\circ} \mathrm{C}$ for $15 \mathrm{~min}$ and poured onto Petri plates (9-10 $\mathrm{cm}$ diameter). After the medium congealed, the examined isolates were inoculated in a thin line. The plates with the medium were incubated at $37^{\circ} \mathrm{C}$ for $24 \mathrm{~h}$. An area 4 times wider than the tested strain growth line was considered a positive result.

\section{Evaluation of Capacity of Methicillin-Resistant CNS to Produce $\beta$-Lactamase}

Determination of the CNS ability to produce $\beta$-lactamase was carried out using the $\beta$-Lactamase Test (Oxoid). The nitrocefin-impregnated tip of a stick was immersed in the colony of CNS strains on the agar medium, and a small number of bacterial cells was collected. The results were read after $5 \mathrm{~min}$, and a stick color change to pink-red was considered positive.

\section{Molecular Study}

DNA was extracted from bacterial cells using the Genomic Mini kit (A\&A Biotechnology, Gdansk, Poland) according to the manufacturer's instructions (http://aabiot/home.pl/aabiop/PDF/Genomic\%20 Mini_PL.pdf).

Real-time PCR was carried out using the Corbett apparatus. Pairs of primers specific to the mecA, tetK, ermA, bap, fnbA, and eno genes were used (Table 1). The PCR was carried out in real time using SYBR Green 1 dye, in thin-walled test tubes with a capacity of $100 \mu \mathrm{L}$. The DyNAmo HS SYBR Green qPCR Kit (Finnzymes, Vantaa, Poland) was used, to conduct a high-specificity reaction.

The $20-\mu \mathrm{L}$ reaction mixture consisted of the following components: $2 \mu \mathrm{L}$ of the DNA matrix, $7.2 \mu \mathrm{L}$ of water, $0.4 \mu \mathrm{L}$ of each primer (final concentration $50 \mathrm{pM}$ ), and $10 \mu \mathrm{L}$ of Master Mix containing a hot start version of the modified polymerase Tbr (Thermus brockianus), a buffer for the polymerase Tbr, dNTP, $\mathrm{MgCl}_{2}$, and the intercalating SYBR Green 1 dye.

We evaluated the susceptibility of microorganisms to antibiotics by determining antibiotic MIC according to the method of double dilution in a liquid base of Mueller-Hinton broth (CM0405; Oxoid) using flatbottomed 96-well microplates. We examined Staph. chromogenes for its susceptibility to amoxicillin with clavulanic acid (Fluka, Buchs, Switzerland), ampicillin (Roth, Karlsruhe, Germany), ceftiofur (Fluka), lincomycin (Roth), erythromycin (Roth), penicillin (Roth), and oxytetracycline (Roth). Antibiotic concentrations ranged between 0.06 and $32 \mu \mathrm{g} / \mathrm{mL}$. Initial antibiotic solutions were diluted 1:100 in Mueller-Hinton bouillon; then, $100 \mu \mathrm{L}$ of each operating solution was added to the first holes of titracit plates and transferred to the next. The final concentration of the antibiotic in each dent was 2 times lower than in the previous one. Bacterial colonies collected from the agar plates were suspended in $4 \mathrm{~mL}$ of $0.85 \% \mathrm{NaCl}$ solution until a density of 0.5 on the McFarland scale was reached.

\section{RESULTS}

Staph. chromogenes made up $11.3 \%$ of all CNS isolated from cows with subclinical mastitis. No macroscopic changes in milk or symptoms in the cows were found, and SCC ranged between 216,000 and $568,000 / \mathrm{mL}$ of milk (average $356,000 / \mathrm{mL}$ of milk).

Phenotypic factors responsible for the pathogenicity of Staph. chromogenes in isolate from subclinical mastitis are presented in Table 2 . The capacity to produce slime was confirmed in 24 isolates (63.2\%); however, non-slime-producing isolates exhibited the bap gene. Fibronectin-binding and laminin-binding proteins were not detected. The bap and eno genes were also not detected in reference strains, but the $f n b A$ gene was detected in Staphylococcus epidermidis ATCC 12228

Table 1. Primers for PCR

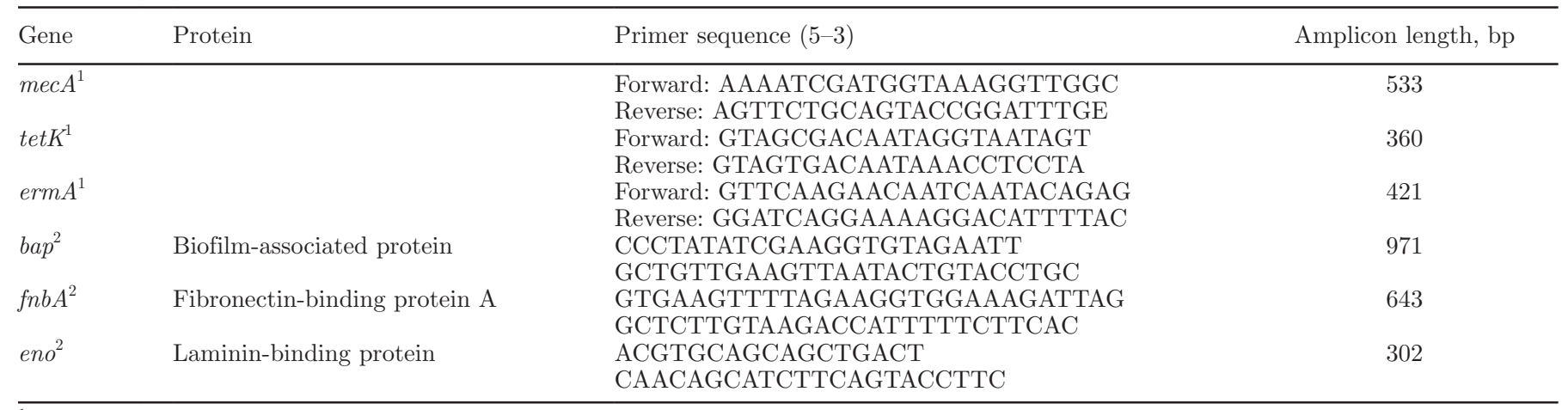

${ }^{1}$ Used according to Kot et al. (2012).

${ }^{2}$ Used according to Simojoki et al. (2012). 
Table 2. Factors of virulence among isolates of Staphylococcus chromogenes from subclinical mastitis in cows

\begin{tabular}{lcc}
\hline & \multicolumn{2}{c}{$\begin{array}{c}\text { Staphylococcus chromogenes } \\
(\mathrm{n}=38)\end{array}$} \\
\cline { 2 - 3 } Factor of virulence & No. & $\%$ \\
\hline Production of slime & 24 & 63.2 \\
Production of protease & 29 & 76.3 \\
$\beta$-Lactamase & 4 & 10.5 \\
\hline
\end{tabular}

(Table 3). The capacity to produce protease was observed in 29 isolates of Staph. chromogenes (76.3\%).

Table 4 shows the MIC for 6 antimicrobial agents against 38 isolates of Staph. chromogenes isolated from subclinical mastitis in cows. The $\beta$-lactams (amoxicillin, ampicillin, and cephalosporins) are widely used to treat bovine mastitis, and we observed these antibiotics as highly effective. Ceftiofur showed the highest activity ( $89.5 \%$ of isolates were susceptible; Table 5 ), and ceftiofur MIC ranged from 0.06 to $2 \mu \mathrm{g} / \mathrm{mL}$ for the susceptible isolates. The minimum concentrations required to inhibit growth of $90 \%\left(\mathrm{MIC}_{90}\right)$ and $50 \%$ $\left(\mathrm{MIC}_{50}\right)$ of the isolates for ceftiofur were at or lower than the cutoffs recommended by the Clinical and Laboratory Standards Institute (CLSI, 2013; 2 and $0.06 \mu \mathrm{g} / \mathrm{mL}$, respectively). Only 4 isolates (10.5\%) were resistant to ceftiofur. A substantial percentage of the isolates were susceptible to amoxicillin with clavulanic acid $(84.2 \%)$ and to ampicillin (81.6\%). The MIC for both amoxicillin and ampicillin were located in the confidence intervals of $<0.06$ to $>32 \mu \mathrm{g} / \mathrm{mL}$, but a difference was recorded in $\mathrm{MIC}_{90}$ and $\mathrm{MIC}_{50}$ levels for these antibiotics. Growth of $50 \%$ of tested isolates was inhibited by $0.06 \mu \mathrm{g} / \mathrm{mL}$ amoxicillin and $0.125 \mu \mathrm{g} / \mathrm{mL}$ ampicillin. However, to inhibit growth of $90 \%$ of tested isolates, $1 \mu \mathrm{g} / \mathrm{mL}$ amoxicillin was needed but only $0.5 \mu \mathrm{g} / \mathrm{mL}$ ampicillin. The lowest effectiveness among $\beta$-lactam antibiotics was observed for penicillin $(73.7 \%$ susceptible isolates). The mecA gene was undetected, but $\beta$-lactamase was observed in 4 isolates (10.5\%). The remaining antibiotics were far less effective. Only
$71.1 \%$ of Staph. chromogenes isolates were susceptible to erythromycin, and barely 1 of 11 isolates, which were resistant to erythromycin, had the ermA gene. The lowest activity in vitro was observed for oxytetracycline (63.2\% of isolates were susceptible). The tetK gene was detected in 6 of 14 isolates, which exhibited phenotypic susceptibility to oxytetracycline.

\section{DISCUSSION}

The CNS play substantial role as etiological factors in mastitis in cows, and Staph. chromogenes is one of the most commonly isolated species of CNS (Taponen et al., 2006; Lüthje and Schwarz, 2006; Sawant et al., 2009; Frey et al., 2013; Tomazi et al., 2015).

Rajala-Schultz et al. (2004), who studied milk samples from cows affected by mastitis in the United States from 2001 to 2002, identified 158 CNS species, with the highest percentage being Staph. chromogenes. A dozen or so years earlier, a study conducted by Matthews et al. (1991) also demonstrated that the most prevalent species of CNS obtained from milk was Staph. chromogenes. In a previous study (Bochniarz et al., 2013), we found that Staph. chromogenes was the most frequently isolated species of CNS in subclinical mastitis. This species has also been isolated in heifers with mastitis (De Vliegher et al., 2003; Sawant et al., 2009).

Similar to other species of CNS, Staph. chromogenes is among the physiological bacterial flora that exist on the skin of mammary glands. In the literature, it has been widely shown how this pathogen colonizes the skin and apexes of the teats. White et al. (1989) isolated Staph. chromogenes from $62 \%$ of samples from teat skin, and Trinidad et al. (1990) recorded the same species in $43 \%$ of samples from the teat apexes. In a study by De Vliegher et al. (2003), Staph. chromogenes was prevalent among CNS isolated from the teat canals of both heifers and cows in the dry period and postpartum.

Staphylococcus chromogenes most often causes barely noticeable subclinical mastitis (Bochniarz et al., 2013). The early diagnosis and treatment of mastitis leads to

Table 3. Distribution of genes among isolates of Staphylococcus chromogenes from subclinical mastitis in cows, and control reference strains of Staphylococcus aureus and Staphylococcus epidermidis

\begin{tabular}{|c|c|c|c|c|c|}
\hline \multirow[b]{2}{*}{ Gene } & \multicolumn{2}{|c|}{$\begin{array}{c}\text { Staphylococcus } \\
\text { chromogenes }(\mathrm{n}=38)\end{array}$} & \multirow{2}{*}{$\begin{array}{l}\text { Staph. aureus } \\
\text { (ATCC 43300) }\end{array}$} & \multirow{2}{*}{$\begin{array}{l}\text { Staph. aureus } \\
\text { (ATCC 29213) }\end{array}$} & \multirow{2}{*}{$\begin{array}{l}\text { Staph. epidermidis } \\
\text { (ATCC 12228) }\end{array}$} \\
\hline & No. & $\%$ & & & \\
\hline mecA & 0 & 0.0 & + & - & - \\
\hline tetK & 6 & 15.8 & - & + & + \\
\hline ermA & 1 & 2.6 & + & - & - \\
\hline bap & 0 & 0.0 & - & - & - \\
\hline$f n b A$ & 1 & 2.6 & - & - & + \\
\hline eno & 0 & 0.0 & - & - & - \\
\hline
\end{tabular}


Table 4. Susceptibility levels $(\mu \mathrm{g} / \mathrm{mL})$ among isolates $(\mathrm{n}=38)$ of Staphylococcus chromogenes from subclinical mastitis in cows

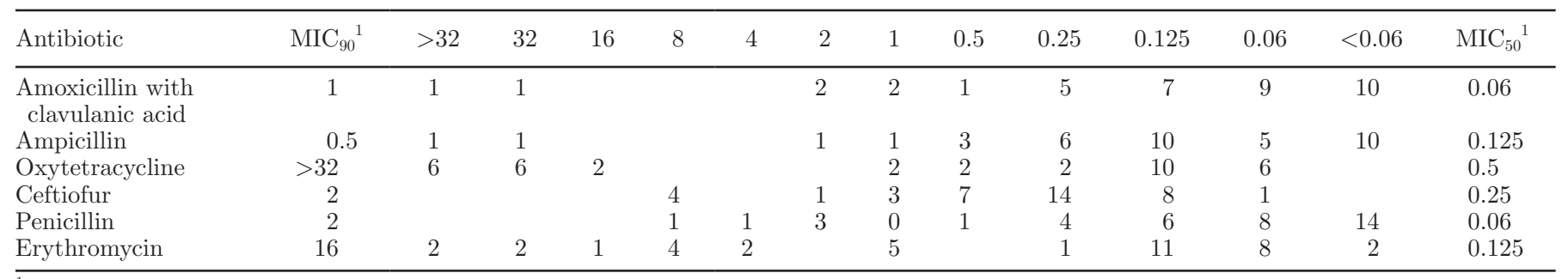

${ }^{1} \mathrm{MIC}_{90}$ and $\mathrm{MIC}_{50}$ are the minimum concentrations required to inhibit growth of 90 and $50 \%$ of the isolates tested, respectively.

quicker elimination of infection. In some cases, mastitis caused by Staph. chromogenes has resolved on its own. Aarestrup and Jensen (1997) found that infection of the udder caused by Staph. chromogenes was observed shortly after delivery and disappeared quickly. In contrast, infection caused by other species of CNS lasted for long periods or recurred during the same lactation. In a study carried out by Taponen et al. (2007), persistent CNS infection in the mammary gland was observed in $46 \%$ of tested quarters and transient infection in 54\%; Staph. chromogenes was the dominant species in both transient and persistent infections. Therefore, from the studies, we can infer that this pathogen can survive in the udder regardless of desquamating epithelium and the flow of milk during milking.

Adhesion of microorganisms to host tissues is the first stage of pathogenesis in udder infections (Aguilar et al., 2001). In this process, Staphylococcus spp. proteins, such as laminin-binding protein and fibronectin-binding protein, are vital because they allow the pathogen to bind to the host's extracellular matrix (Cree et al., 1994). The next stage, which simplifies the survival of pathogens in the udder, is the creation of bacterial biofilm. Biofilms are structured communities of bacterial cells enclosed in a self-produced matrix and attached to surfaces (Costerton et al., 1999). Biofilm protects the bacterial cells against the host's immunological defenses and against the activity of antibiotics used to treat mastitis (Costerton et al., 1999; Melchior et al., 2006). In vitro tests indicate that Staphylococcus spp. that reside within biofilm are 10 to 1,000 times

Table 5. Antimicrobial susceptibility among isolates $(\mathrm{n}=38)$ of Staphylococcus chromogenes

\begin{tabular}{lcr}
\hline Antibiotic & $\begin{array}{c}\text { Sensitive, } \\
\text { no. }(\%)\end{array}$ & $\begin{array}{r}\text { Resistant, } \\
\text { no. }(\%)\end{array}$ \\
\hline Amoxicillin with clavulanic acid & $32(84.2)$ & $6(15.8)$ \\
Ampicillin & $31(81.6)$ & $7(18.4)$ \\
Oxytetracycline & $24(63.2)$ & $14(36.8)$ \\
Ceftiofur & $34(89.5)$ & $4(10.5)$ \\
Penicillin & $28(73.7)$ & $10(26.3)$ \\
Erythromycin & $27(71.1)$ & $11(28.9)$ \\
\hline
\end{tabular}

more resistant to antibiotics than plankton cells of the same strains. Biofilm formation in Staphylococcus spp. is associated with several factors, including biofilmassociated protein (Cucarella et al., 2004). The results of our study did not confirm the presence of both the bap gene and the fnbA and eno genes in tested isolates. However, an important role in adhesion may be played by the mucus capsule in Staphylococcus spp., which enables bacterial adhesion and the production of bacterial biofilm (Aguilar et al., 2001; Lee and Lee, 2006). In the present study, we observed the ability to produce slime, facilitating adhesion of bacterial cells, in more than $60 \%$ Staph. chromogenes isolates. Simojoki et al. (2012) observed slime production in Congo red agar analysis with glucose supplementation in $14.1 \%$ isolates of CNS from mastitis, although Staph. chromogenes were less common than other species (only 1/55 isolates was slime-positive). Similar to our findings, the bap gene was not detected any of the 84 CNS isolates originating from mastitis Simojoki et al. (2012).

Protease also plays a significant role in the survival of Staphylococcus spp. in the udder, because of its ability to bind hemoglobin, lactoferrin, and transferrin in the place of iron binding. In this way, iron is detached and is more accessible to pathogen cells (Lacasse et al., 2008; Chaneton et al., 2008). Staphylococci require higher concentrations of iron for formation of biofilm than for vegetative growth (Weinberg, 2004). In the present study, the capacity to form protease was observed in $76.3 \%$ of isolates.

We observed the highest effectiveness against Staph. chromogenes isolates for cephalosporins, amoxicillin, and ampicillin. The lowest percentage of resistant isolates was observed for ceftiofur (10.5\%), which was the only antibiotic for which the $\mathrm{MIC}_{90}$ and $\mathrm{MIC}_{50}$ were at or below the cutoffs recommended by CLSI (2013). Lüthje and Schwarz (2006) recorded even higher rates of effectiveness for ceftiofur: only $0.3 \%$ of CNS isolates were resistant. In the present study, the $\beta$-lactam antibiotic with the lowest activity was penicillin. Methicillin resistance, determined by the mecA gene, was not found. Watts and Owens (1989) also demonstrated that amoxicillin with clavulanic acid was highly effec- 
tive (100\% susceptible isolates) but that penicillin had lower effectiveness. Lüthje and Schwarz (2006) found that among CNS strains, including those dominated by Staph. chromogenes, there were no isolates resistant to penicillin, and the $\mathrm{MIC}_{90}$ and $\mathrm{MIC}_{50}$ for penicillin was at $\leq 0.006 \mathrm{ng} / \mathrm{mL}$ and $0.12 \mathrm{ng} / \mathrm{mL}$, respectively. These values were lower than the cutoffs for penicillin recommended by the CLSI (2013). In a study conducted by Salmon et al. (1998), the $\mathrm{MIC}_{90}$ value for penicillin against CNS was $0.25 \mathrm{ng} / \mathrm{mL}$. In contrast, the $\mathrm{MIC}_{90}$ for penicillin in a study by Gentilini et al. (2002) was 4 $\mathrm{ng} / \mathrm{mL}$, and in a study by Thorberg et al. (2009), it was $32 \mathrm{ng} / \mathrm{mL}$. These significant differences in MIC result from the fact that various CNS are often regarded as a single group. It is advisable to evaluate CNS species individually, because they can exhibit different susceptibility patterns (Sawant et al., 2009).

The literature indicates that among antibiotics used to treat bovine mastitis, erythromycin showed low activity against CNS (Lüthje and Schwarz, 2006; Piessens et al., 2012). In the present study, although a significant percentage of isolates were resistant to erythromycin (28.9\%) and tetracycline (38.7\%), the $\mathrm{ermA}$ gene was detected only in 1 isolate, and the tet $K$ gene was found in 6 isolates. Contrary to the present study, Devriese et al. (2002) did not record resistance to erythromycin, and only 2/70 isolates of Staph. chromogenes were resistant to oxytetracycline. On the other hand, in Frey et al. (2013) found that a significant percentage of CNS isolates obtained from bovine milk were more often resistant to penicillin than to erythromycin or tetracycline $(23.3,7.0$, and $15.8 \%$, respectively). Similar to the present study, the mecA gene was not detected, regardless of isolates' resistance to penicillin.

\section{CONCLUSIONS}

To cause mastitis, pathogens must possess the ability to adhere and survive in cows' udders. In our study, tested isolates of Staph. chromogenes did not have the gene encoding biofilm-associated protein (bap) or the genes encoding proteins responsible for binding with extracellular matrix ( $f n b A$ and $e n o$ ). However, a significant percentage of isolates produced the slime needed in biofilm formation. We also observed that a high percentage of tested isolates could form protease, which facilitates access to the iron necessary for the growth of Staphylococcus spp. We also found that most of the $\beta$-lactam antibiotics were highly effective against Staph. chromogenes. The results of the study were satisfactory, because cephalosporins, amoxicillin with clavulanic acid, and ampicillin are among the antibiotics most commonly used to treat mastitis in cows.

\section{REFERENCES}

Aarestrup, F. M., and N. E. Jensen. 1997. Prevalence and duration of intramammary infection in Danish heifers during the peripartum period. J. Dairy Sci. 80:307-312.

Aguilar, B., B. Amorena, and M. Iturralde. 2001. Effect of slime on adherence of Staphylococcus aureus isolated from bovine and ovine mastitis. Vet. Microbiol. 78:183-191.

Bochniarz, M., W. Wawron, and M. Szczubiał. 2013. Coagulase-negative staphylococci (CNS) as an aetiological factor of mastitis in cows. Pol. J. Vet. Sci. 16:487-492.

Chaneton, L., L. Tirante, J. Maito, J. Chaves, and L. E. Bussmann. 2008. Relationship between milk lactoferrin and etiological agent in the mastitic bovine mammary gland. J. Dairy Sci. 91:1865-1873.

CLSI (Clinical and Laboratory Standards Institute). 2013. Performance Standards for Antimicrobial Disk and Dilution Susceptibility Tests for Bacteria Isolated from Animals. Vol. 28, No. 8 Approved standard, VET01-A4. 4th ed. CLSI, Wayne, PA.

Costerton, J. W., P. S. Stewart, and E. P. Greenberg. 1999. Bacterial biofilms: A common cause of persistent infections. Science 284:1318-1322.

Cree, R. G. A., P. Aleljung, M. Paulsson, W. White, W. C. Noble, A. Ljungh, and T. Wadström. 1994. Cell surface hydrophobicity and adherence to extracellular matrix proteins in two collections of methicillin-resistant Staphylococcus aureus. Epidemiol. Infect. 112:307-314.

Cucarella, C., M. A. Tormo, C. Ubeda, M. P. Trotonda, M. Monzon, C. Peris, B. Amorena, I. Lasa, and J. R. Penades. 2004. Role of biofilm-associated protein bap in the pathogenesis of bovine Staphylococcus aureus. Infect. Immun. 72:2177-2185.

De Vliegher, S., H. Laevens, L. A. Devriese, G. Opsomer, J. L. M. Leroy, H. W. Barkema, and A. de Kruif. 2003. Prepartum teat apex colonization with Staphylococcus chromogenes in dairy heifers is associated with low somatic cell count in early lactation. Vet. Microbiol. 92:245-252.

Devriese, L. A., M. Baele, M. Vaneechoutte, A. Martel, and F. Haesebrouck. 2002. Identification and antimicrobial susceptibility of Staphylococcus chromogenes isolated from intramammary infections of dairy cows. Vet. Microbiol. 87:175-182.

Freeman, D. J., F. R. Falkiner, and C. T. Keane. 1989. New method for detecting slime production by coagulase negative staphylococci. J. Clin. Pathol. 42:872-874.

Frey, Y., J. P. Rodriguez, A. Thomann, S. Schwendener, and V. Perreten. 2013. Genetic characterization of antimicrobial resistance in coagulase-negative staphylococci from bovine mastitis milk. J. Dairy Sci. 96:2247-2257.

Gentilini, E., G. Denamiel, A. Betancor, M. Rebuelto, M. R. Fermepin, and R. A. de Tores. 2002. Antimicrobial susceptibility of coagulase-negative staphylococci isolated from bovine mastitis in Argentina. J. Dairy Sci. 85:1913-1917.

Kot, B., M. Piechota, K. M. Wolska, A. Frankowska, E. Zdunek, T. Binek, E. Kłopotowska, and M. Antosiewicz. 2012. Fenotypic and genotypic antimicrobial resistance of staphylococci from bovine milk. Pol. J. Vet. Sci. 15:677-683.

Lacasse, P., K. Lauzon, M. S. Diarra, and D. Petitclerc. 2008. Utilization of lactoferrin to fight antibiotic-resistant mammary gland pathogens. J. Anim. Sci. 86:66-71.

Lee, C. Y., and J. C. Lee. 2006. Staphylococcal capsule. Pages 456-463 in Gram-Positive Pathogens. V. A. Fischetti, R. P. Novick, J. J. Ferretti, D. A. Portnoy, and J. I. Rood, ed. ASM Press, Washington DC.

Lüthje, P., and S. Schwarz. 2006. Antimicrobial resistance of coagulase-negative staphylococci from bovine subclinical mastitis with particular reference to macrolide-lincosamide resistance phenotypes and genotypes. J. Antimicrob. Chemother. 57:966-969.

Makovec, J. A., and P. L. Ruegg. 2003. Results of milk samples submitted for microbiological examination in Wisconsin from 1994 to 2001. J. Dairy Sci. 86:3466-3472.

Matthews, K. R., R. J. Harmon, and B. E. Langlois. 1991. Effect of naturally occurring coagulase-negative staphylococci infections on 
new infections by mastitis pathogens in the bovine. J. Dairy Sci. $74: 1855-1859$.

Melchior, M. B., H. Vaarkamp, and J. Fink-Gremmels. 2006. Biofilms: A role in recurrent mastitis infections? Vet. J. 171:398-407.

Melchior, M. B., M. H. van Osch, T. J. Lam, J. C. Vernooij, W. Gaastra, and J. Fink-Gremmels. 2011. Extended biofilm susceptibility assay for Staphylococcus aureus bovine mastitis isolates: Evidence for association between genetic makeup and biofilm susceptibility. J. Dairy Sci. 94:5926-5937.

Moon, J. S., A. R. Lee, H. M. Kang, E. S. Lee, M. N. Kim, Y. H. Paik, Y. H. Park, Y. S. Joo, and H. C. Koo. 2007. Phenotypic and genetic antibiogram of methicillin-resistant staphylococci isolated from bovine mastitis in Korea. J. Dairy Sci. 90:1176-1185.

Paulsson, M., A. Ljungh, and T. Wadström. 1992. Rapid identification of fibronectin, vitronectin, laminin, and collagen cell surface binding proteins on coagulase-negative staphylococci by particle agglutination assays. J. Clin. Microbiol. 30:2006-2012.

Piessens, V., S. De Vliegher, B. Verbist, G. Braem, A. Van Nuffel, L. De Vuyst, M. Heyndrickx, and E. Van Coillie. 2012. Characterization of coagulase-negative Staphylococcus species from cows milk and environment based on bap, icaA, and mecA genes and phenotypic susceptibility to antimicrobials and teat dips. J. Dairy Sci. 95:7027-7038.

Pitkälä, A, M. Haveri, S. Pyörälä, V. Myllys, and T. Honkanen-Buzalski. 2004. Bovine mastitis in Finland 2001-prevalence, distribution of bacteria, and antimicrobial resistance. J. Dairy Sci. 87:2433-2441.

Pyörälä, S., and S. Taponen. 2009. Coagulase-negative staphylococciEmerging mastitis pathogens. Vet. Microbiol. 134:3-8.

Rajala-Schultz, P. J., K. L. Smith, J. S. Hogan, and B. C. Love. 2004. Antimicrobial susceptibility of mastitis pathogens from first lactation and older cows. Vet. Microbiol. 102:33-42.

Salmon, S. A., J. L. Watts, F. M. Aarestrup, J. W. Pankey, and J. R. Yancey. 1998. Minimum inhibitory concentrations for selected antimicrobial agents organisms isolated from the mammary glands of dairy heifers in New Zealand and Denmark. J. Dairy Sci. 81:570578.

Sawant, A. A., B. E. Gillespie, and S. P. Oliver. 2009. Antimicrobial susceptibility of coagulase-negative Staphylococcus species isolated from bovine mastitis. Vet. Microbiol. 134:73-81.
Simojoki, H., P. Hyvönen, C. Plumed, S. Ferrer, S. Taponen, and S. Pyörälä. 2012. Is the biofilm formation and slime producing ability of coagulase-negative staphylococci associated with the persistence and severity of intramammary infection? Vet. Microbiol. 158:344-352.

Taponen, S., J. Koort, J. Bjorkorth, H. Saloniemi, and S. Pyörälä. 2007. Bovine intramammary infections caused by coagulase-negative staphylococci may persist throughout lactation according to amplified fragment length polymorphism-based analysis. J. Dairy Sci. 90:3301-3307.

Taponen, S., H. Simojoki, M. Haveri, H. D. Larsen, and S. Pyörälä 2006. Clinical characteristics and persistence of bovine mastitis caused by different species of coagulase-negative staphylococci identified with API or AFLP. Vet. Microbiol. 115:199-207.

Thorberg, B. M., M. L. Danielsson-Them, U. Emanuelson, and K. P. Waller. 2009. Bovine subclinical mastitis caused by different types of coagulase-negative staphylococci. J. Dairy Sci. 92:4962-4970.

Tomazi, T., J. L. Gonçalves, J. R. Barreiro, M. A. Arcari, and M. V. dos Santos. 2015. Bovine clinical intramammary infection caused by coagulase-negative staphylococci increases somatic cell count but has no effect on milk yield or composition. J. Dairy Sci. 98:3071-3078.

Tremblay, Y. D., D. Lamarche, P. Chever, D. Haine, S. Messier, and M. Jacques. 2013. Characterization of the ability of coagulasenegative staphylococci isolated from the milk of Canadian farms to form biofilms. J. Dairy Sci. 96:234-246.

Trinidad, P., S. C. Nickerson, and T. K. Alley. 1990. Prevalence of intramammary infection and teat canal colonization in unbred and primigravid dairy heifers. J. Dairy Sci. 73:107-114.

Waller, K. P., A. Aspan, A. Nyman, Y. Persson, and U. G. Andersson. 2011. CNS species and antimicrobial resistance in clinical and subclinical bovine mastitis. Vet. Microbiol. 152:112-116.

Watts, J. L., and W. E. Owens. 1989. Prevalence of staphylococcal species in four dairy herds. Res. Vet. Sci. 46:1-4.

Weinberg, E. D. 2004. Suppression of bacterial biofilm formation by iron limitation. Med. Hypotheses 63:863-865.

White, D. G., R. J. Harmon, J. E. S. Matos, and B. E. Langlois. 1989. Isolation and identification of coagulase-negative Staphylococcus spp. from bovine sites and streak canals of nulliparous heifers. J. Dairy Sci. 72:1886-1892. 